\title{
Self-Efficacy, Task Performance and Contextual Performance: A Sri Lankan Experience
}

\author{
U.W.M.R. Sampath Kappagoda \\ Faculty of Management Studies, Rajarata University of Sri Lanka, Mihintale, Sri Lanka \\ Email: sampathkappagoda@gmail.com
}

How to cite this paper: Sampath Kappagoda, U.W.M.R. (2018) Self-Efficacy, Task Performance and Contextual Performance: A Sri Lankan Experience. Journal of Human Resource and Sustainability Studies, 6, 161-170.

https://doi.org/10.4236/jhrss.2018.62034

Received: March 30, 2018

Accepted: June 1, 2018

Published: June 4, 2018

Copyright $\odot 2018$ by author and Scientific Research Publishing Inc. This work is licensed under the Creative Commons Attribution International License (CC BY 4.0).

http://creativecommons.org/licenses/by/4.0/

\begin{abstract}
The relationship between self-efficacy and job performance has long been established. But, there is limited research on self-efficacy and different dimensions of job performance and the extent of the association has not been investigated comprehensively in the context of the Sri Lankan banking sector. Therefore, the purpose of this study was to investigate the impact of self-efficacy on task performance and contextual performance of the employees in the banking sector in Sri Lanka. The data were randomly collected from a sample of 176 managers and 357 non-managerial employees in the banking sector in Sri Lanka. A questionnaire was administered to the employees to measure their self-efficacy, task performance, and contextual performance. The collected data were analyzed using correlation coefficient and regression analysis. The results of the study indicated that self-efficacy had significantly and positively correlated with task performance and contextual performance. According to the findings, the employees' trust on their capabilities to organize and execute courses of action required to accomplish the task has significantly and positively correlated with the behaviors that are directly related with the completion of the job and with the extra role supporting behaviors which are not directly related to the job.
\end{abstract}

\section{Keywords}

Contextual Performance, Self Efficacy, Task Performance

\section{Introduction}

Job performance is the observable behavior that employees do in their jobs that are relevant to the goals of the organization [1]. Traditionally, job performance was evaluated in terms of the proficiency with which an individual carried out the tasks that were specified in their job description. However, the changing na- 
ture of work and organizations has challenged the traditional view of job performance [2]. In 1993, Borman and Motowidlo [3] introduced several taxonomies that have been developed to explore the domain of job performance. One of the fundamental distinctions made in these taxonomies is between in role performance or behavior that is directly related to the job tasks or requirements and extra-role performance, or behaviors that are not directly related to the job but contributed to organizational outcomes [4]. Borman and Motowidlo (1993) [3] divided the performance domain into the task and contextual performance, which distinguishes between behaviors that are directly related to the job and behavior that contribute to organizational outcomes in ways that are not related to core job functions.

In today's hypercompetitive business environment, task performance and contextual performance of the employees have been identified as crucial factors in achieving organizational performance. Therefore, managers have given more concern about managing the task and contextual performance of their employees. They have identified different factors that can affect job performance. Among them experience, ability, performance feedback, pay increase, job security, leader behavior, group process [5]; individual characteristics [6]; motivation [7]; organizational culture [8]; effort [9]; organizational structure [10]; leadership [9]; organizational commitment [11] [12]; job involvement [12]; personality [10]; emotional intelligence [12]; job satisfaction [12] are few antecedents of task and contextual performance. In addition, Self-efficacy has frequently been identified as an important motivational factor that influences performance [13]. The self-efficacy is the belief of the employees about their abilities to do their tasks. Self-efficacy is one of the most theoretically developed, researched and state like constructs that is explained under positive organizational behavior and psychological capital. In reviewing the literature, self-efficacy and work outcomes have highly correlated [14] [15]. It also a core constructs of predicting work related effectiveness. A meta-analysis of 114 studies found that self-efficacy had a strong relationship with job performance than other organizational behavior constructs [14]. Researchers stated that people who hold strong self-efficacy beliefs tend to be more satisfied with their job and demonstrate more commitment [16] and have lower absenteeism [17].

Despite the importance of self-efficacy, there are few researches in Sri Lankan context. These researches have focused entrepreneurial self-efficacy in the SME sector. The banking sector was selected for this study by considering its great contribution to the Sri Lankan economy. Economy or production process largely depends upon how efficiently the financial sector in general and the banks in particular perform the basic functions of financial transformations. The performance of the banking sector directly affects to the other industrial and service sectors of the economy. There is a huge competition within this sector. All the banks try to gain competitive advantages through the service quality. The human resource is the most influencing factor in improving the service quality. If the 
employees are performing well in the banks, it can be predicted that service quality of the bank is high [2]. However, in this hypercompetitive business environment, the full potential of human resource should be utilized to gain distinctive competitive advantages. With the emergence of the positive psychology, the researchers have found the importance of positive strengths of the people as a new source of distinctive competitive advantage. Among them self-efficacy has been given much attention in the recent past as a highly influencing factor on job performance. On the other hand, the extra role performance that is not directly related to the job, but contributes to organizational outcomes has not given much attention in evaluating the job performance. They have given much attention to the task performance despite the importance of both classifications. In reviewing the empirical evidence, the researchers have given little attention on the influence of positive strength like self-efficacy on different categorization of job performance. There are no researches can be found on self-efficacy and its impact on task and contextual performance in the Sri Lankan baking sector. Therefore, investigating the impact of self-efficacy on different taxonomies (task and contextual) of the job performance of Sri Lankan banking sector employees is the objective of this research study.

\section{Theoretical Basis and Research Hypothesis}

\subsection{Self Efficacy, Task Performance and Contextual Performance}

Stajkovic and Luthans (1998) [18] defined the concept of self-efficacy relevant to the work place as person's confidence in his or her abilities to make ready for the motivation, cognitive resources and a way of acting necessary to effectively perform a specific task within a certain context. The concept of self-efficacy is based on Bandura's (1997) [19] social cognitive theory, which is an approach to understand human cognition, action, motivation, and emotion that assumes we are active shapers, rather than simply passive reactors to our environments [19]. Bandura (1982) [20] defined self-efficacy as a person's perception or belief of "how well one can execute courses of action required to deal with prospective situations". In 1986, he defined self-efficacy as "people's judgments of their capabilities to organize and execute courses of action required to attain designated types of performances". Schwoerer et al. (2005) [21] defined self-efficacy as "the beliefs that an individual has that he or she can successfully carry out the actions necessary to accomplish the intentions". Self-efficacy can be viewed as a concept of perceived competence and the probability that people estimate that they can take on a particular task as an estimate of their self-efficacy. Self-efficacy is state-like construct and can be changed with new information, experience and learning. According to Bandura (1997) [19] mastery experience or performance attainment, vicarious experience or modeling, social persuasion, psychological arousal can be used to develop the efficacy among the people.

Borman and Motowidlo (1993) [22] described a two-factor theory of job performance in which most jobs consist of task performance and contextual per- 
formance. They defined task performance as the behavior that is directly linked to completion of the job. Task related behaviors contribute to the technical core of the organization. Behavior in the domain of task performance is usually recognized as a formal requirement of an individuals' job. Job description often explicitly stipulates that the job holders must perform these activities. Borman and Motowidlo (1993) [22] defined contextual performance as an individual's performance, which maintains and enhances an organization's social network and the psychological climate that supports technical tasks. Furthermore, they explained that contextual performance includes activities that may not represent formal work tasks, although they still make an important contribution to the effectiveness of an organization. This type of performance is often not written in a job description, but it is considered to be an important component of job performance.

\subsection{Research Hypothesis}

Although there have been much of the research on self-efficacy and job performance relationship, there are few studies that have conducted a direct empirical comparison of self-efficacy, task performance and contextual performance relationship. Bandura (1986) [23] defined self-efficacy as "people's judgments of their capabilities to organize and execute courses of action required to attain designated types of performances". Rigotti, Schyns, \& Mohr (2008) [24] defined self efficacy as "Self-efficacy", defined as "the competence that a person feels concerning the ability to successfully fulfill the tasks involved in his or her job". If the people have trust in their capabilities they develop self-disciplined behavior so as to improve their performance. This can be used as a motivational tool. If the employees have confidence in what they have to do, they motivate to complete the tasks efficiently and effectively. As a result of that, the in the role and extra role behaviors of them will improve. Bandura (1977) [25] has extensively researched the impact of self-efficacy on job performance has found a positive effect. Some researchers found the same results in their research studies [15] [26] [27] [28] [29] [30]. Their works have most recently validated by a meta-analysis covering over 21,000 subjects. And also Jawahar, Meurs, Ferris \& Hochwarter (2008) [31] found positive relationships between self efficacy, task performance and contextual performance. Furthermore, they found self-efficacy be more strongly related to task than to contextual performance. However the positive psychologists argued that self efficacy to be highly related with contextual performance. Individuals with high self-efficacy beliefs set higher career goals, put in more effort, and pursue career strategies that lead to the achievement of those goals. Self-efficacy regulates the way in which an individual perceives his or her competence. This perception influences an individual's ability to complete a task and a set, attainable goal [32]. Hackett (1995) [33] and Lent \& Hackett (1987) [34] confirmed that individuals who lack confidence in skills they possess are less likely to engage in tasks in which those skills are required, 
and they will more quickly give up in the face of difficulty. Self-efficacious employees take greater initiative in their occupational self-development and generate ideas that help to improve work processes [35]. According to Trentham, Silvern \& Brogdon (1985) [36], employees who have high self-efficacy are more satisfied and committed to work. Borgogni, Russo, Miraglia \& Vecchione (2013) [17] also found same results and explained that self-efficacy can lead to higher job satisfaction and to greater work attendance. Therefore, it can be predicted that employees with self efficacy may perform both extra role behaviors and in role behaviors well. Based on this argument, the following hypotheses are proposed.

$\mathrm{H}_{1}$ : Self efficacy is significantly and positively correlated with task performance of the employees.

$\mathrm{H}_{2}$ : Self efficacy is significantly and positively correlated with contextual performance of the employees.

\section{Research Methodology}

In this study, the researcher tries to examine the impact of self-efficacy on task performance and contextual performance. Therefore, the purpose of this study is hypothesis testing that seeks to explore the relationships among variables. The current study employed a correlational study in order to explore the relationship between employees' self-efficacy (independent variable) and their task and contextual performance (dependent variables). This field study is conducted in a natural environment in the banking sector under minimal interference with non-contrived settings. This study is a cross sectional study. For this purpose, data will have to be collected from each employee in the banking sector in Sri Lanka. Therefore, the unit of analysis of this research is "individual".

The population of this study is the managers and non-managerial employees in the banking sector in Sri Lanka. It consists of 24 Licensed Commercial Banks (LCB) and 9 Licensed Specialised Banks (LSB). The sample for this study was initially derived by randomly selected 220 managers and 440 non-managerial employees who employed in the banking sector in Sri Lanka throughout the seven provinces. The response rate was $81 \%$. The final sample consists of 174 managerial employees and 352 non managerial employees.

The managers and non-managerial employees' task and contextual performance were the dependent variables and self-efficacy of the managers and non-managerial employees were the independent variable of this research. These variables were measured using standard instruments. The questionnaire was separated into four sections for demographic data, self-efficacy, task performance and contextual performance. Seven questions were included to get the demographic information.

The employees' self-efficacy was measured using a standard questionnaire which was originally developed by Luthans and colleagues (2007) [37]. It was included 05 questions. This questionnaire has been validated by using the confir- 
matory factor analysis across multiple samples [37]. In this research the minimum factor loading was 0.584 and KMO value 0.815 . The Cronbach alpha was 0.806. Task performance was measured using a standard questionnaire developed by Borman, Ackerman and Kubisiak (1994) [38]. This instrument includes 08 questions. The minimum factor loading for 8 items was 0.554 and KMO value was 0.878 . The contextual performance was measured using a questionnaire developed by Motowidlo and Van Scotter (1994) [39]. The instrument includes 13 items. The minimum factor loading was 0.505 and KMO value was 0.914 . The Cronbach alpha was 0.892 .

\section{Results}

The researcher examined the level of self efficacy, task performance and contextual performance of the managerial and non-managerial employees. According to the results of Table 1, the levels of self-efficacy, task performance and contextual performance were relatively higher among the employees.

The results of the correlation coefficient among self-efficacy, task performance and contextual performance of the employees in the banking sector in Sri Lanka are presented in Table 2. According to the results, the correlation between self-efficacy and task performance $(r=0.490, p<0.01)$ was significant and positive. The results of regression analysis that depicts in Table 3 reported the similar relationship $(\beta=0.457, p<0.01)$. The correlation between self-efficacy and contextual performance $(\mathrm{r}=0.477, p<0.01)$ was significant and positive. The regression results in Table 4 also indicated the significant and positive relation$\operatorname{ship}(\beta=0.414, p<0.01)$.

Table 1. The results of univariate analysis.

\begin{tabular}{ccc}
\hline Variables & Mean & Std. Deviation \\
Self-Efficacy & 3.91 & 0.434 \\
Task Performance & 4.03 & 0.436 \\
Contextual Performance & 4.20 & 0.401 \\
\hline
\end{tabular}

Table 2. Correlation coefficient between independent variable and dependent variables.

\begin{tabular}{cccc}
\hline Variables & 1 & 2 & 3 \\
\hline 1. Self-Efficacy & - & \\
2. Task Performance & $0.490^{\star *}$ & - & - \\
3. Contextual Performance & $0.477^{\star *}$ & $0.778^{\star *}$ & \\
\hline
\end{tabular}

${ }^{*} p<0.05,{ }^{* *} p<0.01$.

Table 3. Results of regression analysis—self efficacy and task performance.

\begin{tabular}{ccccccc}
\hline $\boldsymbol{\beta}$ & $\mathbf{R}$ & R Square & Adjusted R Square & $\begin{array}{c}\text { Std. Error of the } \\
\text { Estimate }\end{array}$ & F & Sig. \\
\hline 0.457 & 0.490 & 0.240 & 0.239 & 0.375 & 168.137 & 0.000 \\
\hline
\end{tabular}


Table 4. Results of regression analysis-self efficacy and contextual performance.

\begin{tabular}{ccccccc}
\hline $\boldsymbol{\beta}$ & $\mathbf{R}$ & R Square & $\begin{array}{c}\text { Adjusted } \mathrm{R} \\
\text { Square }\end{array}$ & $\begin{array}{c}\text { Std. Error of the } \\
\text { Estimate }\end{array}$ & $\mathbf{F}$ & Sig. \\
\hline 0.414 & 0.477 & 0.227 & 0.236 & 0.354 & 156.348 & 0.000 \\
\hline
\end{tabular}

\section{Discussion, Conclusions and Recommendation}

The objective of this study was to examine the impact of self-efficacy on task performance and contextual performance of the employees in the banking sector in Sri Lanka. The results of the correlation coefficient and regression analysis indicated that self-efficacy of employees has significantly and positively correlated with both task performance and contextual performance. Therefore, the two hypotheses can be accepted. Concurrently, this finding was consistent with the earlier finding of Carter, Nesbit, Badham, Parker \& Li-Kuo Sung (2016) [26]; Randhawa (2004) [27]; Lai and Chen (2012) [28]; De Clercq, Haq and Azeem (2018) [30]. The self-efficacy has significantly explained $24 \%$ of the variance in task performance and it has explained $22.7 \%$ of the variance in contextual performance. According to the results, there are significant linear relationships between self-efficacy and task performance $(\mathrm{F}$ value $=168)$ and self-efficacy and contextual performance $(\mathrm{F}$ value $=156)$.

The findings show that the employees' trust on their capabilities to organize and execute courses of action required to accomplish the task has significantly and positively correlated with the behaviors that are directly related with the completion of the job which was stipulated by the job description. In turn, the employees' self efficacy has also correlated with the extra role, supporting behaviors which are not directly related to the job. Today, the researchers and practitioners have agreed the importance of extra role behaviors in addition to the task behaviors to enhance the organizational performance. The study concluded that the self-efficacy of the employees is very important to improve the task and contextual performance of the employees. Based on the findings of this study, it is therefore recommended that the workshops and training program should be designed and organized to boost the self-efficacy of the employees and those changes will help to enhance the task and contextual performance of the employees in the banking sector.

\section{Directions for Further Research}

The present study has been provided many potential paths for future researchers. In this study self-efficacy, task performance and contextual performance were the major variables of interest. However, exploration of how self-efficacy regulates other areas in an organization may be fruitful. For example, the question of how self-efficacy affects leadership styles, job satisfaction, organizational commitment, job involvement, withdrawal intention, family conflict, stress etc. The research study attempted to demonstrate the direct relationship between self-efficacy and each dependent variable. The further researches would be ad- 
vantages to explore potential mediators and moderators for these connections.

\section{References}

[1] Campbell, J.P., McHenry, J.J. and Wise, L.L. (1990) Modeling Job Performance in a Population of Jobs. Personnel Psychology, 43, 313-333. https://doi.org/10.1111/j.1744-6570.1990.tb01561.x

[2] Kappagoda, U.W.M.R.S., Othman, H.Z.F. and De Alwis, G. (2014) Psychological Capital and Job Performance: The Mediating Role of Work Attitudes. Journal of Human Resource and Sustainability Studies, 2, 102-116. https://doi.org/10.4236/jhrss.2014.22009

[3] Borman, W.C. and Brush, D.H. (1993) More Progress towards Taxonomy of Managerial Performance Requirements. Human Performance, 6, 1-21. https://doi.org/10.1207/s15327043hup0601_1

[4] Shaffer, R.D. and Shaffer, M.A. (2005) Emotional Intelligence Abilities, Personality and Workplace Performance. Academy of Management Proceedings, M1-M6.

[5] Waldman, D.A. and Spangler, W.D. (1989) Putting Together the Pieces: A Closer Look at the Determinants of Job Performance. Human Performance, 2, 29-59.

https://doi.org/10.1207/s15327043hup0201_2

[6] Susana, J., Pauline, A., Dean, N.M. and Awang, R. (2015) Individual Characteristics and Job Performance: Generation Y at SMEs in Malaysia. Procedia-Social and Behavioral Sciences, 170, 137-145. https://doi.org/10.1016/j.sbspro.2015.01.023

[7] Mensah, E.B.K. and Tawiah, K.A. (2016) Employee Motivation and Work Performance: A Comparative Study of Mining Companies in Ghana. Journal of Industrial Engineering and Management, 9, 255-309. https://doi.org/10.3926/jiem.1530

[8] Shahzad, F. (2014) Impact of Organizational Culture on Employees' Job Performance: An Empirical Study of Software Houses in Pakistan. International Journal of Commerce and Management, 24, 219-227. https://doi.org/10.1108/IJCoMA-07-2012-0046

[9] Mulki, J.P., Caemmerer, B. and Heggde, G.S. (2014) Leadership Style, Salesperson's Work Effort and Job Performance: The Influence of Power Distance. Journal of Personal Selling \& Sales Management, 35, 3-22. https://doi.org/10.1080/08853134.2014.958157

[10] Robbins, P.S. (2003) Organizational Behaviour: Concepts, Controversies, and Applications. 5th Edition, Prentice Hall International Inc., London.

[11] Jaramillo, F., Mulki, J.P. and Marshall, G.W. (2005) A Meta-Analysis of the Relationship between Organizational Commitment and Salespeople Job Performance: 25 Years of Research. Journal of Business Research, 58, 705-714. https://doi.org/10.1016/j.jbusres.2003.10.004

[12] Kappagoda, U.W.M.R.S. (2012) Job Satisfaction and Its Impact on Task and Contextual Performance in the Banking Sector in Sri Lanka. Proceedings of the 1st International Symposium 2011 on Post-War Economic Development through Science, Technology and Management, 23.

[13] Eccles, J. S. and Wigfield, A. (2002) Motivational Beliefs, Values, and Goals. Annual Review of Psychology, 53, 109-132. https://doi.org/10.1146/annurev.psych.53.100901.135153

[14] Yakin, M. and Erdil, O. (2012) Relationships between Self-Efficacy and Work Engagement and the Effects on Job Satisfaction: A Survey on Certified Public Accountants, Procedia-Social and Behavioral Sciences, 58, 370-378. 
https://doi.org/10.1016/j.sbspro.2012.09.1013

[15] Judge, T.A., Jackson, C.L., Shaw, J.C., Scott, B.A. and Rich, B.L. (2007) Self-Efficacy and Work-Related Performance: The Integral Role of Individual Differences. Journal of Applied Psychology, 92, 107-127. https://doi.org/10.1037/0021-9010.92.1.107

[16] Olusol, O. (2011) Intrinsic Motivation, Job Satisfaction and Self-Efficacy as Predictors of Job Performance of Industrial Workers in Ijebu Zone of Ogun State. The Journal of International Social Research, 4, 569-577.

[17] Borgogni, L., Russo, S.D., Miraglia, M. and Vecchione, M. (2013) The Role of Self-Efficacy and Job Satisfaction on Absences from Work. European Review of Applied Psychology, 63, 129-136. https://doi.org/10.1016/j.erap.2012.08.007

[18] Stajkovic, A.D. and Luthans, F. (1998) Self-Efficacy and Work-Related Performance: A Meta-Analysis. Psychological Bulletin, 124, 240-261. https://doi.org/10.1037/0033-2909.124.2.240

[19] Bandura, A. (1997) Self-Efficacy: The Exercise of Control. Freeman, New York.

[20] Bandura, A. (1982) Self-Efficacy Mechanism in Human Agency. American Psychologist, 37, 122-147. https://doi.org/10.1037/0003-066X.37.2.122

[21] Schwoerer, C.E., May, D.R., Hollensbe, E.C. and Mencl, J. (2005) General and Specific Self-Efficacy in the Context of a Training Intervention to Enhance Performance Expectancy. Human Resource Development Quarterly, 16, 111-129. https://doi.org/10.1002/hrdq.1126

[22] Borman, W.C. and Motowidlo, S. (1993) Expanding the Criterion Domain to Include Elements of Contextual Performance. In: Schmitt, N. and Borman, W.C., Eds., Personnel Selection in Organizations, Jossey-Bass, San Francisco, 71-98.

[23] Bandura, A. (1986) Social Foundations of Thought and Action: A Social Cognitive Theory. Prentice-Hall, Englewood Cliffs.

[24] Rigotti, T., Schyns, B. and Mohr, G. (2008) A Short Version of the Occupational Self-Efficacy Scale: Structural and Construct Validity across Five Countries. Journal of Career Assessment, 16, 238-255. https://doi.org/10.1177/1069072707305763

[25] Bandura, A. (1977) Self-Efficacy: Toward a Unifying Theory of Behavioral Change. Psychological Review, 84, 191-215. https://doi.org/10.1037/0033-295X.84.2.191

[26] Carter, W.L., Nesbit, P.L., Badham, R.J., Parker, S.K. and Sung, L.-K. (2016) The Effects of Employee Engagement and Self-Efficacy on Job Performance: A Longitudinal Field Study. The International Journal of Human Resource Management. https://doi.org/10.1080/09585192.2016.1244096

[27] Randhawa, G. (2004) Self-Efficacy and Work Performance: An Empirical Study. Indian Journal of Industrial Relations, 30, 336-346.

[28] Lai, M.C. and Chen, Y.C. (2012) Self-Efficacy, Effort, Job Performance, Job Satisfaction, and Turnover Intention: The Effect of Personal Characteristics on Organization Performance. International Journal of Innovation, Management and Technology, 3, 387-391.

[29] Iroegbu, M.N. (2015) Self Efficacy and Work Performance: A Theoretical Framework of Albert Bandura's Model, Review of Findings, Implications and Directions for Future Research. Psychology and Behavioral Sciences, 4, 170-173. https://doi.org/10.11648/j.pbs.20150404.15

[30] De Clercq, D., Haq, I.U. and Azeem, M.U. (2018) Self-Efficacy to Spur Job Performance: Roles of Job-Related Anxiety and Perceived Workplace Incivility. Management Decision, 56, 891-907. https://doi.org/10.1108/MD-03-2017-0187

[31] Jawahar, I.M., Meurs, J.A., Ferris, G.R. and Wayne, A. (2008) Self-Efficacy and Po- 
litical Skill as Comparative Predictors of Task and Contextual Performance: A Two-Study Constructive Replication. Human Performance, 21, 138-157. https://doi.org/10.1080/08959280801917685

[32] Pajares, F. and Schunk, D.H. (2001) Self-Beliefs and School Success: Self-Efficacy, Self-Concept, and School Achievement. In: Riding, R.J. and Rayner, S.G., Eds., Self Perception, Ablex, Westport, 239-265.

[33] Hackett, G. (1995) Self-Efficacy in Career Choice and Development. In: Bandura, A., Ed., Self-Efficacy in Changing Societies, Cambridge University Press, New York, 232-258.

[34] Lent, R.W. and Hackett, G. (1987) Career Self-Efficacy: Empirical Status and Future Directions. Journal of Vocational Behaviour, 30, 347-382.

https://doi.org/10.1016/0001-8791(87)90010-8

[35] Speier, C. and Frese, M. (1997) Generalized Self-Efficacy as a Mediator and Moderator between Control and Complexity at Work and Personal Initiative: A Longitudinal Field Study in East Germany. Human Performance, 10, 171-192. https://doi.org/10.1207/s15327043hup1002_7

[36] Trentham, L., Silvern, S. and Brogolon, R. (1985) Teacher Efficacy and Teacher Competency Ratings. Psychology in Schools, 22, 343-352. https://doi.org/10.1002/1520-6807(198507)22:3<343::AID-PITS2310220317>3.0.CO $\underline{; 2-0}$

[37] Luthans, F., Avolio, B.J., Avey, J.B. and Norman, S.M. (2007) Positive Psychological Capital: Measurement and Relationship with Performance and Satisfaction. Personnel Psychology, 60, 541-572. https://doi.org/10.1111/j.1744-6570.2007.00083.x

[38] Borman, W.C., Ackerman, L.D. and Kubisiak, U.C. (1994) Development of a Performance Rating Program in Support of Department of Labor Test Validation Research (Contract Nos. 93-2 and 93-3). Cooperative Personnel Services, Sacremento.

[39] Motowidlo, S.J. and Van Scotter, J.R. (1994) Evidence That Task Performance Should Be Distinguished from Contextual Performance. Journal of Applied Psychology, 79, 475-480. https://doi.org/10.1037/0021-9010.79.4.475 